\title{
Exchange Rate Volatility and Productivity Growth: the Role of Liability Dollarization
}

\author{
Kenza Benhima * \\ UNIVERSITY OF LAUSANNE
}

August 2010

\begin{abstract}
This paper studies how liability dollarization conditions the effect of exchange rate flexibility on growth. It develops a model with credit-constrained firms facing liquidity shocks denominated in tradables while their revenues are both in tradable and nontradables. With frictions in the reallocation between tradables and nontradables, a peg is more growth-enhancing than a float in countries with dollarized debt because it stabilizes firms' cash flows. However, this relative advantage diminishes when dollarization decreases. These theoretical predictions are confirmed by an empirical analysis on a panel of 76 countries spanning 1995-2004: the higher the degree of dollarization, the more negative the impact of exchange rate flexibility on growth.
\end{abstract}

Key Words: Exchange rate regimes, Growth, Liability dollarization.

JEL Class.: O16, O24, O41, O42.

${ }^{*}$ University of Lausanne, UNIL-Dorigny, Extranef, room 250, 1015 Lausanne. TEL: (+41) (0) 21.692.36.92. Email: Kenza.Benhima@unil.ch 


\section{Introduction}

The choice of exchange rate regime and its impact on economic performance is among the most controversial issues in macroeconomic policy. The empirical works on the growth effect of exchange rate volatility conclude either on exchange rate neutrality, or on a different effect in industrial and developing countries. ${ }^{1}$ Some recent studies suggest that the failure of the empirical literature at bringing a stable, clear-cut effect of exchange volatility to the fore may be due to nonlinear effects: Razin and Rubinstein (2006) allow the exchange rate regime to have both a direct effect on short-term growth, and an indirect one that is channeled through the crisis probability, while Aghion et al. (2009) argue that the choice of exchange rate regime should depend on financial development. Using a sample of 83 countries spanning the years 1960-2000, they show that real exchange rate volatility can have a significant impact on the long-term rate of productivity growth, but the effect depends critically on the countries' level of financial development.

This paper argues that, besides financial development, another prominent feature of emerging markets can explain the contrasting effects of exchange rate flexibility on growth in developing and industrial countries, namely liability dollarization, also referred to as "original sin ", that is the inability of developing countries to borrow in their own currency. The focus on dollarization is justified by the idea that, on the one hand, the volatility of cash flows matters for long-run growth, as empirical works tend to show (Aghion et al., 2005, 2007); on the other, liability dollarization impairs firms' capacities to hedge currency risk. This idea is tackled both theoretically and empirically.

On the theoretical side, I borrow from Aghion et al. (2009) to build a stylized model in which volatility matters for long-run growth: when firms face credit constraints, negative shocks to their cash flows deteriorate their innovating capacities, whereas a positive shock will not have any impact if the firm is already at its optimum. This asymmetric effect of shocks under financial frictions rationalizes the negative impact of cash-flow volatility on innovation and growth: the consequences of negative cash flow shocks are not offset by the effects of positive shocks. Besides, wages are sticky, which makes exchange rate policy matter for cash flow volatility. I supplement this framework with two important features to account for the role of financial dollarization under different exchange rate regimes: 1) the production is split into tradable and nontradable goods while firms face costs in tradable goods when innovating; 2) the firms' debt can be partially or completely denominated in terms of tradable goods. The question then is: depending on the level of dollarization, what regime stabilizes better the cash flows -that is, profits net of debt repayments- in terms of tradable goods, thus allowing a better average financing capacity?

The relative stabilizing properties of exchange rate regimes is a recurring question in the theoretical literature. In particular, whether liability dollarization reverses the superiority of the flexible regime has

\footnotetext{
${ }^{1}$ Baxter and Stockman (1989) were the first to bring this "instability puzzle" forward. The literature has since been inconclusive on the subject: Husain et al. (2005) find that exchange rate flexibility is growth-enhancing in industrial countries and neutral in developing economies, while Dubas et al. (2005), relying on an alternative exchange-rate classification, find that a fixed exchange rate has good growth performances in the latter while it is neutral in the former. Levy-Yeyati and Sturzenegger (2003) find that, on average, countries with a fixed exchange rate regime grow at a slower rate.
} 
been a particularly compelling issue. ${ }^{2}$ Cespedes et al. (2002) and Devereux et al. (2006) argue that, when using a full-fledged DSGE model, the conventional ranking is unchanged. However, Cook and Cook (2002) and Cook (2004) find, with different specifications, that the picture is more nuanced. Here, I develop a stylized model with one feature which is essential in evaluating the different performance of regimes, namely the frictions in adjusting consumption between tradable and nontradable goods, which makes the nontradable sector particularly vulnerable. These frictions have been emphasized by Christiano et al. (2004) and Mendoza (2001), but in other contexts than the choice of exchange rate regimes (namely, currency crises and sudden stops). Indeed, with low elasticity of substitution between tradable and nontradable goods, the output measured in foreign currency is more volatile under flexible regimes. As a result, floating exchange rates are detrimental for growth as compared to fixed exchange rates, especially in highly dollarized countries. In low-dollarization countries, this ranking can be reversed thanks to the hedging properties of domestically-denominated debt.

To test the basic hypothesis that exchange rate flexibility has a more negative impact in dollarized countries, standard growth regressions are used. Those standard growth regressions are augmented by a measure of exchange rate flexibility, a measure of external dollarization and the interaction term of exchange rate flexibility and dollarization. The results are based on a dynamic panel of 76 emerging and industrial countries between 1995 and 2004 described above. To measure exchange rate flexibility, I use the Levy-Yeyati and Sturzenegger (2002) classification of exchange rate regimes. The dollarization measure is the external "original sin" taken from Hausmann et al. (2001) and Hausmann and Panizza (2003). The empirical results show that exchange rate flexibility is more detrimental to growth in dollarized countries than in non-dollarized countries, which is in line with the model's predictions. These findings are robust to various specifications and to the treatment of endogeneity.

Among the empirical works on liability dollarization at the macro level, only a few have examined the overall growth impact of original sin. ${ }^{3}$ Bleaney and Vargas (2009) is closer to our approach. They investigate the role of the debt composition to explain the negative effect of depreciation on growth in emerging markets. Our approach differs in that it focuses on the interaction of debt composition with exchange rate volatility -and more generally, exchange rate management, and not exchange rate depreciations.

Section 2 presents a stylized model of growth and monetary policy. Section 3 derives the empirical implications of the model regarding the link between growth and exchange rate volatility. Section 4 tests these empirical predictions.

\footnotetext{
${ }^{2}$ Early contributions include, among others, Calvo (2000); Krugman (2000); Aghion et al. (2000).

${ }^{3}$ See for example on liability dollarization Arteta (2005); Calvo et al. (2004); De Nicolo et al. (2003); Reinhart et al. (2003); Levy-Yeyati (2006); Eichengreen et al. (2005); Bleaney and Vargas (2009) and in particular, on its impact on growth Reinhart et al. (2003); Levy-Yeyati (2006); Bleaney and Vargas (2009)
} 


\section{A stylized monetary model with growth}

In this section, we present a stylized model to illustrate the impact of exchange rate management on growth in the presence of liability dollarization. The model combines three important features: (i) growth proceeds from innovation undertaken by firms with sufficient funds to meet liquidity shocks; (ii) wages are sticky, implying that the transmission of macroeconomic shocks is shaped by the choice of exchange rate regime; (iii) firms' debt can be partially or completely denominated in dollars.

First, we describe how, in the presence of credit constraints, growth depends on firms' profits and thus on the interplay between liability dollarization and the real exchange rate, but only in a partial equilibrium approach. Second, the model is closed by introducing monetary policy and households.

\subsection{Firms and the growth process}

Consider a small open economy with a continuum of firms, indexed by $i \in[0,1]$. Firms produce both tradable goods $T$, which are identical to the outside world good, and nontradable ones $N$. There are two currencies: the domestic currency (peso) and the foreign one (dollar).

Firms are price-taker and competitive so that the law of one price applies in the sector of tradables:

$$
P_{t}^{T}=S_{t} P_{t}^{T *}
$$

where $P_{t}^{T}$ and $P_{t}^{T *}$ are respectively the domestic (peso) and foreign (dollar) price of tradable goods and $S_{t}$ is the nominal exchange rate. $P_{t}^{T *}$ is assumed to be constant and normalized to one. Thus $P_{t}^{T}=S_{t}$.

The timing within period $t$ can be summarized as follows. First, wages are preset. The entrepreneurs borrow $D_{t}$ to be able to innovate in period $t+1$ : that is upgrade $A_{t}$, the level of productivity. An aggregate productivity shock occurs in the tradable sector, firms hire labor $L_{t}$ and produce $A_{t} Y_{t}^{T}$ and $A_{t} Y_{t}^{N}$, respectively the production of tradable and nontradable goods. Firms repay their debt $D_{t}$, and pay the wages $A_{t} W_{t} L_{t}$, with $A_{t} W_{t}$ the wage rate and $L_{t}$ labor. Firm $i, i \in[0,1]$ faces a liquidity shock $A_{t} \Phi_{t}^{i}$ in dollars. If the liquidity shock is financed, then the firm is able to innovate and recovers $A_{t} \Phi_{t}^{i}$. If it is not financed, then the firm cannot innovate and disappears at the end of the period. Finally, firms distribute profits.

First, the process governing the evolution of productivity is presented to determine how growth depends on current cash flows. We then determine cash flows.

\subsubsection{The evolution of productivity}

Innovation process The innovation process is specified as follows: if the firm is able to overcome the liquidity shock of period $t$, then its $t+1$ productivity is upgraded by a factor $\delta>1$. Otherwise, the firm keeps the same productivity level. As a result, aggregate productivity evolves according to:

$$
A_{t+1}=\delta \rho_{t} A_{t}+\left(1-\rho_{t}\right) A_{t}
$$

with $\rho_{t}$ the proportion of innovating firms. The aggregate growth rate is therefore $g=(\delta-1) \rho_{t}$. 
Credit market imperfections and liquidity shocks To be able to innovate, the firm has to pay a fixed cost $D_{t}=d A_{t}(d>0)$ in dollars at the beginning of period $t$. Firms start the period without funds, so they must borrow $D_{t}$. For tractability, firms' indebtedness is introduced under the form of a fixed cost. It is also assumed that the cost of borrowing is lower than the expected value of innovation, which implies that firms always choose to pay the fixed cost. This cost can be viewed as spending on $R \& D$, learning expenses or investment in a new technology.

At the end of period $t$, a liquidity shock $A_{t} \Phi_{t}^{i}$, where $\Phi_{t}^{i}$ is independently and identically distributed across firms, threatens the completion of the innovation process of firm $i$. If the firm does not finance this cost, it cannot innovate. If it meets this cost, it recovers $A_{t} \Phi_{t}^{i}$ at the end of the current period. For simplicity, it is also assumed that the liquidity cost can be financed with a zero interest rate. As a consequence, the innovation cost is neutral regarding the net profit of the current period. Therefore, it is always profitable for the firms to finance the liquidity shock. $A_{t} \Phi_{t}^{i}$ can be viewed as the cost induced by a delay, typically in an imported equipment, or any transitory shock that would ruin the business unless there is enough liquidity to overcome it.

The access to financial markets is therefore critical to determine the innovation capacity of the firm at this point, as Aghion et al. (2009) show. However, here, in order to stress the specific role of liability dollarization, we assume that the firm has no access at all to credit markets at this stage, so firms are able to overcome the transitory liquidity shock if and only if their cash flow is sufficient to meet the cost:

$$
\Pi_{t} \geq \Phi_{t}^{i}
$$

where $\Pi_{t}$ is the cash flow of the firm expressed in dollars and scaled by $A_{t}$.

Firms have the same cash flows $\Pi_{t}$ and differ only regarding the liquidity shock $\Phi_{t}^{i}$. Therefore, $\rho_{t}$, the proportion of firms which are not constrained (and thus of innovating firms), is the proportion of firms whose liquidity shock is lower than $\Pi_{t}$ :

$$
\rho_{t}=P\left(\Phi_{t}^{i}<\Pi_{t}\right)=F\left(\Pi_{t}\right)
$$

where $F$ is the cumulative distribution of $\Phi_{t}^{i}$.

The aggregate growth rate depends directly on the level of cash flows $\Pi_{t}$.

Volatility and growth Here, I give an example of how volatility affects average growth, that is $E\left(\rho_{t}\right)$. Assume that the idiosyncratic liquidity shock $\phi_{t}^{i}$ is uniformly distributed over $(\underline{\phi}, \bar{\phi})$, and that the disturbance on profits $\Pi_{t}$ resulting from the aggregate shock and exchange rate policy is of the following form:

$$
\Pi_{t}=\left\{\begin{array}{l}
E(\Pi)+\sigma^{\pi} \text { with probability } \frac{1}{2} \\
E(\Pi)-\sigma^{\pi} \text { with probability } \frac{1}{2}
\end{array}\right.
$$

with $\sigma^{\pi}$ strictly positive. $\sigma^{\pi}$ is a measure of aggregate volatility around the steady-state profits $E(\Pi)$.

I assume that $E(\Pi)-\sigma^{\pi}>\phi$, which means that in the worst state of nature, there is always a positive fraction of firms that are able to overcome the liquidity shock. Under this reasonable assumption, the 
probability to innovate given the aggregate shock is then:

$$
\rho_{t}=\min \left\{\frac{\Pi_{t}-\underline{\phi}}{\bar{\phi}-\underline{\phi}}, 1\right\}
$$

Taking expectations gives:

$$
E\left(\rho_{t}\right)=\left\{\begin{array}{l}
\frac{E(\Pi)-\underline{\phi}}{\bar{\phi}-\underline{\phi}} \text { if } E(\Pi)+\sigma^{\pi}<\bar{\phi} \\
\frac{E(\Pi)-\underline{\phi}}{\bar{\phi}-\underline{\phi}}-\frac{E(\Pi)+\sigma^{\pi}-\bar{\phi}}{2(\bar{\phi}-\underline{\phi})} \text { otherwise }
\end{array}\right.
$$

The average proportion of innovating firms -and therefore the average growth rate- is clearly decreasing in the size of the aggregate shock $\sigma^{\pi}$. The intuition is that when shocks are small, some firms are constrained for both good and bad aggregate shocks. More volatility would allow more firms to innovate in the good state while preventing more firms from doing so in the bad one, leaving the average proportion of innovating firms unchanged. For large shocks, all firms innovate in the good state. In that case, more volatility would crowd out more firms in the bad state while not allowing more firms to innovate in the good state. The idea is simply that when volatility increases, the gains generated in the good states are exhausted sooner or later, which does not allow to make for the additional losses in bad states.

\subsubsection{Firms' cash-flows}

Production and growth Firms have identical technologies. A firm produces both tradable and nontradable goods. The tradable and nontradable productions of firm $i \in[0,1]$ during period $t$ are respectively denoted by $A_{t} Y_{t}^{T i}$ and $A_{t} Y_{t}^{N i}$ and:

$$
\begin{gathered}
Y_{t}^{T i}=Y_{t}^{T}=e^{u_{t}} \\
Y_{t}^{N i}=Y_{t}^{N}=\sqrt{L_{t}}
\end{gathered}
$$

where $L_{t}$ denotes labor. $Y_{t}^{T i}$ and $Y_{t}^{N i}$ are the firm's productions scaled by the level of productivity and $u_{t}$ is the aggregate productivity shock in the tradable sector, with $u_{t}=\sigma, \sigma>0$ with probability $1 / 2$ and $u_{t}=-\sigma$ with probability $1 / 2$. The labor demand is identical across firms because firms have the same technology. For simplicity, it is assumed that the production of nontradables requires labor while the production of tradables involves no input. This specification has been chosen to capture the fact that the nontradable sector is more labor-intensive than the tradable sector.

Firms choose employment to maximize the nontradable profit $P_{t}^{N} \sqrt{L_{t}}-W_{t} L_{t}$ with respect to $L_{t}$, where $W_{t}$ is the wage scaled by $A_{t}$, and $P_{t}^{N}$ is the peso price of nontradable goods. We get the implicit labor demand function:

$$
W_{t} L_{t}=\frac{P_{t}^{N} Y_{t}^{N}}{2}
$$

Indebtment and dollarization It is assumed that debt $D_{t}=d A_{t}$ is contracted in nominal terms and is denominated either in foreign currency (dollars) or in local currency (pesos). An exogenous fraction $\alpha$ is denominated in dollars while the rest is denominated in pesos. $\alpha$ is the degree of dollarization. 
We assume that the level of dollarization is exogenous. Indeed, the fact that liability dollarization is imposed on developing countries is commonly admitted in the literature. ${ }^{45}$. This financial markets incompleteness is often related to the lack of sound institutions and can therefore be regarded as exogenous. ${ }^{6}$

$r^{*}$, the interest rate on dollar bonds, is fixed internationally. It is assumed that foreigners are risk neutral and value dollars so that $r$, the interest rate on peso bonds, satisfies the following no-arbitrage condition:

$$
E\left(\frac{1+r}{P_{t}^{T}}\right)=1+r^{*}
$$

At the end of period $t$, the firm has therefore to repay in dollars:

$$
\left(\alpha+\frac{1}{P_{t}^{T} E_{t-1} \frac{1}{P_{t}^{T}}}(1-\alpha)\right)\left(1+r^{*}\right) D_{t}
$$

Cash flows The liquidity shock occurs after the firm has paid the wage bill and repaid the debt, so the cash flow in terms of dollars and scaled by $A_{t}$ is $\Pi_{t}=Y_{t}^{T}+\frac{P_{t}^{N}}{P_{t}^{T}} Y_{t}^{N}-\frac{W_{t} L_{t}}{P_{t}^{T}}-\left(\alpha+\frac{1}{P_{t}^{T} E\left(\frac{1}{P_{t}^{T}}\right)}(1-\alpha)\right)(1+$ $\left.r^{*}\right) d$. After replacing the wage bill using labor demand (5), one gets:

$$
\Pi_{t}=\underbrace{Y_{t}^{T}+\frac{1}{2} \frac{P_{t}^{N}}{P_{t}^{T}} Y_{t}^{N}}_{\text {Gross profits }}-\underbrace{\left(\alpha+\frac{1}{P_{t}^{T} E_{t-1}\left(\frac{1}{P_{t}^{T}}\right)}(1-\alpha)\right)\left(1+r^{*}\right) d}_{\text {Debt repayments }}
$$

The cash flows include gross profits, but to get the actual cash on hand, debt repayments must be subtracted from them. Comparing the gross profit component and the debt component of cash flows gives the actual financing capacity of firms.

Because firms' revenues are partly in nontradable goods while the liquidity shock is denominated in tradables, firms face a currency mismatch. According to (6), firms' gross profits are sensitive to nominal exchange rate variations (changes in $P_{t}^{T}$ ). However, the peso-denominated fraction of firms' debt helps them hedge the variations in the nontradable value of their profits. For example, everything else equal, a nominal depreciation implies a fall in the value of gross profits in terms of tradables. If $\alpha=1$, debt

\footnotetext{
${ }^{4}$ See for example Eichengreen and Hausmann (1999).

${ }^{5}$ Yet, some authors find that exchange rate regimes do affect firms' balance sheets. In particular, the adoption of a floating exchange rate regime leads to a higher degree of currency matching (and the opposite for the adoption of fixed regimes), as Galiani et al. (2003) show for the case of Argentina's currency board and Kamil (2008) does for a panel of emerging countries. However, these studies are conducted on developing countries only. On our macro data set, for a given exchange rate regime, developing countries still exhibit higher liability dollarization than industrial ones, which is a symptom of imposed original sin.

${ }^{6}$ Existing explanations point at time inconsistency problems related to the temptation to "default" on local currency debt through inflation (Calvo and Guidotti, 1989), the incidence of implicit debtor guarantees (Burnside et al., 2001) and signaling problems (De la Torre et al., 2003), among others. De Nicolo et al. (2003) provides evidence that the credibility of macroeconomic policy and the quality of institutions are both key determinants of cross-country variations in dollarization.
} 
repayments, in terms of tradables, are immune to exchange rate variations, whereas if $\alpha<1$, a nominal depreciation leads to a decrease in debt repayments in terms of tradables, which alleviates the overall impact of the depreciation on the total cash flows.

However, whether this intuition is robust to general equilibrium is not guaranteed. The following subsection closes the model in order to derive its properties in general equilibrium.

\subsection{Introducing exchange rate policy}

The purpose of this subsection is to examine the impact of exchange rate policy, which is implemented through a monetary instrument, in terms of transmission of shocks to prices and quantities, and therefore to firms' cash flows.

The presence of nominal rigidities (preset wages) implies that monetary policy has real consequences, in particular in terms of cash flows volatility. Some other key assumptions contribute to shape the model's predictions. First, the nontradable sector is more labor-intensive than the tradable one. This is empirically relevant, but it has also an important implication, which is that an output contraction is consistent with a real depreciation. As a result, the peso-denominated debt has hedging properties regarding cash-flows volatility in terms of dollars. Second, the elasticity of substitution between tradables and nontradables is lower than one, which is widely admitted in the literature, but is also key in ranking the flexible and fixed exchange rate regimes in terms of cash-flow volatility.

The model is closed in a simplistic way in order to keep the model as tractable as possible. The following assumptions are made, without loss of generality: (i) the demand addressed to firms is given by consumers without access to financial markets (hand-to-mouth consumers); (ii) the government controls directly the general price level. Finally, (iii) we assume, as in Aghion et al. (2009), that the real wage at the beginning of period $\mathrm{t}$ is assumed equal to some reservation value, $k A_{t} t$ :

$$
\frac{W_{t}}{E\left(P_{t}\right)}=k A_{t}
$$

\subsubsection{Households}

The households do not have access to financial markets, so their program consists simply in allocating their resources between their consumption of tradable and nontradable goods. They maximize their consumption basket $C_{t}$-scaled by the level of productivity $A_{t}$ :

$$
C_{t}=\left[\gamma^{\frac{1}{\theta}} C_{t}^{T \frac{\theta-1}{\theta}}+(1-\gamma)^{\frac{1}{\theta}} C_{t}^{N \frac{\theta-1}{\theta}}\right]^{\frac{\theta}{\theta-1}}
$$

subject to their -scaled- budget constraint:

$$
P_{t}^{T} C_{t}^{T}+P_{t}^{N} C_{t}^{N}=\Pi_{t}+W_{t}^{j} L_{t}^{j}
$$

where $C_{t}^{T}$ and $C_{t}^{N}$ are respectively the consumptions of tradables and nontradables, scaled by $A_{t}$. The households use the dividends (firms' net profits) and their wage to finance their consumption in tradables and nontradables. $\theta$ is the elasticity of substitution between tradable and nontradable goods. It is 
assumed that $\theta<1$, which means that goods are weakly substitutable. This is a standard assumption regarding tradables and nontradables. $0<\gamma<1$ is the weight of tradables in the consumption basket.

The program yields the relative demand for tradables and nontradables:

$$
\frac{P_{t}^{N}}{P_{t}^{T}}=\left(\frac{1-\gamma}{\gamma} \frac{C_{t}^{T}}{C_{t}^{N}}\right)^{\frac{1}{\theta}}
$$

The general price index associated to the household maximization program is the following:

$$
P_{t}=\left(\gamma P_{t}^{T 1-\theta}+(1-\gamma) P_{t}^{N 1-\theta}\right)^{\frac{1}{1-\theta}}
$$

\subsubsection{Monetary policy}

The monetary policy targets either the stability of the general price index - flexible exchange rate:

$$
P_{t}=\bar{P}
$$

or the stability of the nominal exchange rate - fixed exchange rate:

$$
P_{t}^{T}=\overline{P^{T}}
$$

where $\bar{P}$ and $\overline{P^{T}}$ are constant.

\subsubsection{Equilibrium}

Since nontradables cannot be traded internationally, the nontradable output is entirely consumed:

$$
Y_{t}^{N}=C_{t}^{N}
$$

Besides, the tradable consumption is what remains from the tradable production after repaying the debt:

$$
Y_{t}^{T}-\left(\alpha+(1-\alpha) \frac{1}{P_{t}^{T} E\left(\frac{1}{P_{t}^{T}}\right)}\right)\left(1+r^{*}\right) d=C_{t}^{T}
$$

This means that both current accounts, in tradables and nontradables, are balanced. ${ }^{7}$

Definition: For each period $t$, given $A_{t-1}$ and $A_{t}$, a symmetric equilibrium is defined by a set of prices $\left\{P_{t}^{N}, P_{t}^{T}, P_{t}, W_{t}\right\}$ and allocations $\left\{Y_{t}^{N}, Y_{t}^{T}, C_{t}^{N}, C_{t}^{T}, L_{t}\right\}$ that solves the supply of nontradable and tradable goods (3) and (4), the aggregate labor demand (5), the wage-setting equation (7), the relative demand for tradable and nontradable goods (10), the price index (11), one of the two monetary

\footnotetext{
${ }^{7}$ The current account in the tradable sector is balanced because we have assumed that there is no intertemporal trading, that is no asset trade. This assumption simplifies the analysis but is not crucial. Qualitatively, the results would be unchanged if we introduced intertemporal trade in bonds. This is because, as long as there is imperfect risk sharing, a productivity shock leads households to alter their consumption, which is at the origin of the mechanisms of the model. Trade in bonds only limits the impact of productivity shocks on consumption by sharing their effect between current and future consumption; it does not suppress it. The difference with the model without trade in bonds is only quantitative and does not alter the comparison between regimes.
} 
policies (12) or (13) and the equilibrium conditions on the tradable and nontradable markets (14) and (15).

If the equilibrium productions and prices are determined, the values of firms' cash flows $\Pi_{t}$ can be inferred from $(6) .{ }^{8}$

The empirical predictions of the model are derived in the next section by log-linearizing the model around the non-stochastic steady state and by studying the transmission mechanisms under both regimes.

\section{Model's empirical implications}

In this section, I study the differential impact of aggregate shocks on the quantities and prices under both regimes by using the log-linearized version of the model (given in Appendix A) and then derive some conclusions on exchange rate regimes and growth.

In what follws, $x_{t}$ denotes the deviation from the non-stochastic steady state of $X_{t}: x_{t}=\frac{X_{t}-X}{X} \backsim$ $\ln \left(X_{t}\right)-\ln (X)$. Time subscript are dropped for simplicity.

\subsection{Reactions of quantities and prices to shocks}

After log-linearizing the model (see Appendix A for details), the following proposition can be derived:

\section{Proposition 1 (proof in Appendix A):}

After an identical negative (positive) productivity shock in the tradable sector:

- If $\alpha=1$, the production of nontradables ( $y^{N}$ ) falls (rises) more under a peg than under a float. However, the relative price of nontradables $\left(p^{N}-p^{T}\right)$ (henceforth the real exchange rate) experiences a higher depreciation (appreciation) under a float.

- Under a float, the fall (rise) in the production of nontradables and in the real exchange rate is dampened when $\alpha$ diminishes.

The intuition is the following: a negative shock on the productivity of the tradable sector requires a real depreciation (a fall in $p^{N}-p^{T}$ ) which results in a contractionary deflation in the nontradable sector under both regimes, as illustrated in Figure 1. Indeed, in both regimes, a deflation in $p_{N}$ generates a contraction in $y_{N}$ because the nontradable sector uses labor and the wages are predetermined. This negative effect on $y_{N}$ is accentuated under the fixed exchange rate regime because the real depreciation occurs entirely through a deflation in $p^{N}$ while under a flexible regime it is shared between a rise in $p^{T}$ and a fall in $p^{N}$. However, precisely because of the further contraction in $y^{N}$, the real exchange rate depreciation is milder under a peg because it compensates for the fall in $y^{T}$.

\footnotetext{
${ }^{8}$ To obtain the value of the aggregate variables in absolute terms, multiply $\left\{Y_{t}^{N}, Y_{t}^{T}, C_{t}^{N}, C_{t}^{T}\right\}$ by $A_{t}\left(\left\{L_{t}, P_{t}^{N}, P_{t}^{T}, P_{t}\right\}\right.$ are already in absolute terms).
} 
When $\alpha=1$, all the debt is denominated in dollar, so it plays no role in stabilizing the dollar value of cash flows, whatever the exchange rate regime. But when $\alpha$ falls, the consumption of tradables is stabilized under a float thanks to the hedging effect of the peso-denominated debt, which mitigates the required real depreciation and the consecutive adjustment in $y^{N}$, as Figure 1 shows. The impact of a positive shock yields symmetric results.

As a result, the comparative impact of a negative or positive shock on the nontradable production valued in terms of tradables is ambiguous. But the following proposition can be established:

\section{Proposition 2 (proof in Appendix A):}

After an identical negative (positive) productivity shock in the tradable sector:

- If $\alpha=1$, the fall (rise) in the nontradable production valued in terms of tradables $\left(y^{N}+p^{N}-p^{T}\right)$ is larger under a float than under a peg.

- Under a float, this fall (rise) is mitigated when $\alpha$ diminishes.

Take the case of a negative shock on the tradable production. Since tradable and nontradable goods are weakly substitutable $(\theta<1)$, prices move more than quantities. As a result, when $\alpha=1$, the additional fall in the relative price of nontradables under a float offsets the additional fall in nontradable output under a peg. The production of nontradables expressed in tradables therefore falls more under a float than under a peg. Noticeably, the traditional contractionary deflation is present under the fixed exchange rate regime. Despite that, the output in terms of tradables is more affected if the exchange rate freely floats. The existence of frictions in the reallocation between tradable and nontradable goods inside the consumption basket is crucial to generate this result.

When $\alpha$ diminishes, the stabilizing effect of the peso debt on the consumption of tradables makes the response of nontradable production in terms of tradables smoother under a float, because it stabilizes both the production and the real exchange rate, according to Proposition 1. This is illustrated by the behavior of $y^{N}+p^{N}-p^{T}$ in Figure 1. The symmetric effects would hold if the shock is positive.

\subsection{The impact of exchange rate regimes on growth}

If we admit, following the arguments of section 2.1.1, that lower cash-flow volatility yields higher growth through a higher innovating probability, it is possible to infer what regime is preferred in terms of growth.

Proposition 3 (proof in Appendix A):

- If $\alpha=1$, a peg yields higher growth than a float.

- When $\alpha$ decreases, the growth differential between a peg and a float decreases. 
- If the indebtment level and the elasticity of substitution are high and if the share of nontradable production is low, there exist values of $\alpha>0$ such that a float yields higher growth than a peg.

The first point of Proposition 3 is derived directly from Proposition 2. Under complete liability dollarization, a flexible exchange rate regime is characterized by accentuated variations of cash flows expressed in tradables, and therefore by lower average growth. The second point comes from the fact that the peso-denominated debt has two stabilizing effects on firms' cash flows under a float: 1) a direct stabilizing effect through the hedging role of debt repayments in pesos, 2) an indirect stabilizing effect through the stabilization of the nontradable output expressed in terms of tradables (Proposition 2). Thus, under a flexible exchange rate regime, the level of dollarization has a negative impact on growth because it annihilate the hedging properties of the peso-denominated debt. Put differently, the hedging properties of the peso-denominated debt can be exploited to stabilize cash flows only within flexible exchange rate regimes.

The third point states that under certain conditions, when the level of liability dollarization diminishes, the floating regime can even dominate the peg. These condition are those that maximize the hedging properties of debt: a high indebtment level, a low share of nontradable production. Besides, a high elasticity of substitution $\theta$ diminishes the relative advantage of the fixed exchange rate regime in stabilizing gross profits.

Figure 2 shows the behavior of the variance of firms' cash flows under fixed and flexible exchange rate regimes for some parameter values. The dashed lines are constructed under the assumption that the steady-state ratio of debt repayments over the tradable consumption $\eta$ is equal to 0.1 (low level of debt) and the solid lines are drawn under the assumption that $\eta=0.7$ (high level of debt). ${ }^{9}$ Besides, the elasticity of substitution $\theta$ has been set at 0.6 , which is a standard estimate of the elasticity of substitution between tradable and nontradable goods (Lorenzo et al., 2005), and the weight of nontradable goods in the consumption basket $1-\gamma$ as well as in cash flows $\kappa$ are set to 0.6 (Mendoza, 2001). ${ }^{10}$ It appears clearly that the volatility of cash flows under a float increases with the level of dollarization under both parameters' configuration. Under the first hypothesis (low debt), the volatility of cash flows with the flexible exchange rate regime is always higher than with the fixed regime, whereas under the second hypothesis (high debt), the volatility becomes lower with the flexible exchange rate regime for small values of $\alpha$.

As a conclusion, the testable empirical implication of this model is that the fixed exchange rate regime is growth-enhancing as compared to the flexible exchange rate regime in countries with high liability dollarization and that the growth differential is decreasing as the level of dollarization falls. Whether there are values of dollarization for which a float becomes more growth-enhancing than a peg depends on parameters values and has to be determined empirically.

\footnotetext{
${ }^{9}$ See Appendix A for the definition of $\eta$.

${ }^{10}$ See Appendix A for the definition of $\kappa$.
} 


\section{Empirical Analysis}

In this section, the prediction that the level of dollarization conditions the impact of exchange rate regimes on growth is tested. The basic hypothesis is that exchange rate flexibility has a more negative impact in dollarized countries.

To do so, standard growth regressions are used. These regressions are augmented by a measure of exchange rate flexibility, a measure of external dollarization and the interaction term of exchange rate flexibility and dollarization. First, the data and methodology are presented and then the results based on a dynamic panel of 76 countries between 1995 and 2004 are discussed.

\subsection{Data and methodology}

As is common in the growth empirical literature, we work on non-overlapping five-year averages. This transformation aims at filtering business-cycle fluctuations and so allows us to focus on long-run effects only.

\subsubsection{The dependent variable}

The explained variable is the average growth rate of productivity on a five-year period. Productivity is defined as the ratio of real output per worker. Real GDP is in 1995 PPP-adjusted US dollars. The work force and GDP data come respectively from the World Bank (World Development Indicators database) and CEPII (CHELEM database).

\subsubsection{Exchange rate flexibility variable}

The measure of exchange rate flexibility is an index of exchange rate flexibility based on the Levy-Yeyati and Sturzenegger (2002) (henceforth LS) classification of exchange rate regimes. They define exchange rate regimes according to the behavior of three classification variables: changes in the nominal exchange rate, the volatility of these changes, and the volatility of international reserves. Since originally this index is a measure of rigidity, exchange rate regimes are reordered from the more rigid to the more flexible: $\{1,2,3,4\}=\{$ fix, crawling peg, dirty float, float $\}$. This index is averaged over five years.

\subsubsection{Channels of exchange rate flexibility}

First, according to the model, the negative effects of exchange rate flexibility in dollarized countries is originated in the variations of the real exchange rate. We therefore use a measure of the volatility of the real exchange rate in order to test this prediction. We compute this volatility as the standard deviation of annual changes in the logarithm of the World Bank index of real effective exchange rate (REER). In line with the model, this variable is positively correlated with the LS flexibility measure (see Appendix C).

Second, in the model, we assumed the law of one price. The variations in the REER are therefore driven exclusively by the price of nontradable goods relative to tradables. However, violations of the law 
of one price and more generally variation in the terms-of-trade also affect the volatility of the REER in the data. We therefore introduce the standard deviation of annual changes in the terms-of-trade index provided by the World Bank in order to control whether the impact of exchange rate flexibility comes from terms-of-trade volatility or from the relative price of tradables. Besides, this variable could be an important determinant of growth, as shown by Mendoza (1997).

\subsubsection{The dollarization variable}

The most important and most problematic variable is the liability dollarization measure. It is difficult to find a measure which is both accurate and encompassing. Hausmann et al. (2001) and Hausmann and Panizza (2003) provide data that can be used to construct a proxy for liability dollarization for a sample of industrial and developing countries. They provide measures of "original sin", that is the inability of an economy to borrow internationally in its own currency. Their dataset covers 90 industrial and developing countries. They rely on BIS data of the currency breakdown of foreign banks' assets and liabilities and construct three indicators of original sin.

Those measures are restricted de facto to external dollarization and have a small time coverage, but they encompass industrial countries and thus allow a substantial variability in the dollarization index. Their advantage is that they give a good picture of the currency composition of the world's banking sector's assets in the economy -especially for debt securities- and of the ability of countries to hedge currency risk through swaps. The original sin measures are provided as averages for 1993-1998 and 19992001, which allows to use only two 5-year sequences, 1995-1999 and 2000-2004. The dollarization index used in this chapter is computed as the average of the three indicators. This index, called OSIN, ranges from 0 to 1 .

Figure 3 presents the distribution of original sin in industrial and developing countries. It appears that it is concentrated on its maximum value in developing countries, while in industrial countries it is lower on average and shows more variability. Besides, it is noteworthy that the original sin index varies only in $20 \%$ of the countries between 1993-1998 and 1999-2001. Those characteristics of the dollarization variable, that is high persistence and concentration on high values in developing countries, have to be born in mind when choosing the methodology and running the robustness checks.

\subsubsection{Other control variables}

The set of control variables follows Levine et al. (2000) and Aghion et al. (2009): financial development measured as in Beck et al. (1999) by the amount of credit provided by banks and other financial institutions to the private sector (as a share of GDP), education measured as the average years of secondary schooling (Barro and Lee, 2000), inflation and the size of government measured by governement consumption as a percentage of GDP and trade openness measured by the share of exports and imports in GDP (World Bank).

Finally, the usable dataset covers 76 countries and two periods: 1995-1999 and 2000-2004. Appendix B gives the exhaustive list of countries present in both samples and Appendix C provides some descriptive 
statistics.

\subsubsection{Methodology}

The benchmark specification follows Barro and Sala-i Martin (1995), and more specifically Aghion et al. (2009). But, instead of interacting exchange rate flexibility and financial development as Aghion et al. (2009) do, I interact exchange rate flexibility and dollarization. The estimated equation is the following:

$$
\Delta y_{t}^{i}=y_{t}^{i}-y_{t-1}^{i}=(\alpha-1) y_{t-1}^{i}+\gamma_{1} \text { Flex }_{t}^{i}+\gamma_{2} O S I N_{t}^{i}+\gamma_{3} \text { Flex }_{t}^{i} * O S I N_{t}^{i}+d_{t}+\epsilon_{t}^{i}
$$

where $y_{t}^{i}$ is the logarithm of real output per worker in country $i$ at the end of period $t, t=1995-$ 1999, $2000-2004$, Flex $x_{t}^{i}$ is the exchange rate flexibility measure, OSIN $_{t}^{i}$ is the measure of original sin, $d_{t}$ is a time effect and $\epsilon_{t}^{i}$ is the error term.

$\gamma_{1}+\gamma_{3} \operatorname{OSIN}_{t}^{i}$ describes the overall effect of exchange rate flexibility on growth. $\gamma_{1}$ (the linear term) and $\gamma_{1}+\gamma_{3}$ (which is provided as complementary information) can be interpreted respectively as the effect of exchange rate flexibility in low dollarization countries (original $\sin =0$ ) and in high dollarization countries (original $\sin =1$ ). The threshold original sin for which the sign of the overall impact of exchange rate flexibility changes is $\frac{-\gamma_{1}}{\gamma_{3}}$. The estimate for $\frac{-\gamma_{1}}{\gamma_{3}}$ is provided along with its significance test as complementary information in the regressions. Besides, a Wald test for the significance of exchange rate total effect is run.

The main hypothesis to test is whether exchange rate flexibility has a more negative effect on growth when the level of dollarization increases. This would be validated by the data if $\gamma_{3}$ is found significantly negative. Otherwise, the model would be rejected. The second hypothesis is that the threshold original $\sin \frac{-\gamma_{1}}{\gamma_{3}}$ is between 0 and 1 . This would mean that the impact of exchange rate risk on growth switches from positive to negative within the actual range of the original sin measure. The validation of this hypothesis would shed some light on the exchange rate instability puzzle, which could then be explained by the presence of this kind of non-linearities.

Since the model is dynamic, country effects are necessarily correlated with $y_{t-1}^{i}$. The GMM dynamic panel data estimator developed by Arellano and Bond (1991) and Arellano and Bover (1995) is implemented. The persistence of the dollarization data justifies the use of the extended system-GMM estimator elaborated by Blundell and Bond (1998) and Blundell and Bond (2000). Robust two-step standard errors are also computed by following the method of Windmeijer (2004). Using this approach, the issue of the endogeneity of the lagged explained variable is addressed. The set of instruments is selected according to the following assumption: all the explanatory variables except initial income are predetermined and they are uncorrelated with fixed effects. ${ }^{11}$ This assumption has been chosen after excluding more restrictive

\footnotetext{
${ }^{11}$ In practice, (16) is differentiated and the second lag of the endogenous variable $y_{t-2}^{i}$ is used as an instrument for $\Delta y_{t-1}^{i}$, as well as further lags. Though our sample has only two available observations because of the scarcity of dollarization data, we can rely on lags of $y_{t}^{i}$ beyond the limits of our data. To limit the number of instruments, I use only $y_{t-2}^{i}$ and $y_{t-3}^{i}$ to instrument $\Delta y_{t-1}^{i}$. Since we assume that the other regressors are predetermined, we use their first and second lags as instruments. The system-GMM method consists in adding equations (16) in level as additional observations to limit the problem of weak instruments in presence of persistence. $y_{t-1}^{i}$ is then instrumented with $\Delta y_{t-1}^{i}$ and the other regressors in
} 
ones which suffered from weak instruments issues according to the Anderson and Cragg-Donald tests of underidentification. ${ }^{12}$ These tests assess whether the instruments give sufficient information to identify the effect of the variables of interest. The tables report the Hansen test in order to check whether the set of instruments is globally valid.

\subsection{The role of financial dollarization}

Table 1 shows the results of the GMM regression of productivity growth on the set of explanatory variables described earlier, using equation (16).

Consider the impact of exchange rate flexibility and original sin on growth. Regression (1) of Table 1 shows that in our sample, the overall impact of exchange rate flexibility on growth is negative. But, importantly, as column (2) shows, liability dollarization makes the impact of real exchange rate volatility on growth more negative, as conjectured. This is illustrated by the fact that the coefficient of the interaction term of original sin and exchange rate flexibility is significantly negative (at the $5 \%$ level).

As conjectured, the threshold level of liability dollarization above which exchange rate flexibility becomes detrimental to growth is between 0 and $1(0.56)$. As a consequence, on the one hand, the impact of exchange rate flexibility is significantly negative in both specifications when original sin is equal to 1 . On the other hand, exchange rate flexibility has a positive impact on growth in low dollarization countries (the coefficient of the linear term is positive), and this impact is significant. Besides, the total effect of exchange rate flexibility is significant.

Notice that the linear effect of original sin is significantly positive, which is at odds with the findings of Eichengreen et al. (2005) and Levy-Yeyati (2006), who show that the impact of liability dollarization is either negative or unconclusive. However, the negative effect of the linear term does not imply that the overall effect of original sin is positive. When evaluated with the average value of exchange rate flexibility, the impact of original sin is less significant.

To illustrate the magnitude of these effects, consider Poland: between the end of the nineties and the beginning of the 2000s, its index of original sin moved from 0.92 to 0.62 . Considering its LS index (4) during 2000-2004, its growth gain is 0.5 percentage point per year, according to column. Similarly, an entirely dollarized emerging country (original sin index equal to 1) with similar exchange rate flexibility would gain 1 percentage point of annual growth if it equalized its level of dollarization to that of Poland.

The regressions reported in columns (3) and (4) examine the channels of the impact of exchange rate flexibility on growth. Column (3) introduces REER volatility and its interaction with original sin. The interaction of original sin with REER volatility is significantly negative while its interaction with the LS index of exchange rate flexibility becomes non-significant. This means that, as implied by the model, real exchange rate volatility is the main channel through which exchange rate management affects growth.

${ }^{12}$ This assumption has also been chosen for practical reasons. Because of data scarcity, it is impossible to use second order lags of original sin. It can be therefore considered at best as predetermined (the other variables, in particular the lagged explained variable, can still be instrumented thanks to the available higher lags).
} 
Column (4) estimates the impact of REER volatility along with terms-of-trade volatility and their respective interactions with original sin. Neither terms-of-trade volatility nor its interaction with original sin affect growth, whereas the coefficient of the interaction of REER volatility with original sin remains significantly negative. This suggests that the main channel through which REER volatility affects growth is the volatility of the relative price of nontradables.

Aghion et al. (2009) show that financial development makes exchange rate volatility more harmful to growth, as Appendix C shows. However, dollarization is strongly negatively correlated with financial development. In column (5), we test whether original sin is an independent determinant of the relationship between exchange rate volatility and growth. This regression includes the interaction between financial development and exchange rate flexibility. The interaction between exchange rate flexibility and original sin remains significant, which suggests that original sin conditions the impact of exchange rate flexibility on growth independently from financial development. The interaction between financial development and exchange rate flexibility is non-significant. However, given the strong correlation between original sin and financial development, this does not necessarily indicate that financial development is irrelevant in shaping the relationship between exchange rate regimes and growth.

\subsection{Robustness checks}

Columns (1)-(5) of Table 2 provide robustness checks. These robustness checks include adding traditional controls in the growth regression, controlling for crisis episodes, using an alternative measure of original sin and controlling for the heterogeneity between industrial and developing countries. The same method of two-stage system-GMM and Windmeijer (2004) small sample robust standard errors is used.

\subsubsection{Additional controls}

As column (1) of Table 2 shows, the inclusion of additional controls does not change the results: the interaction term between original sin and exchange rate flexibility is still significantly negative at the $5 \%$ level. Among the new variables, inflation and education show up as significant. The lack of price stability has a negative influence on growth while education has a positive impact, which in line with the traditional findings of the literature and with common wisdom.

\subsubsection{Currency crisis}

Column (2) presents further robustness checks. The question tackled here is the role of currency crises. Since episodes of crisis-driven devaluations occur mainly during fixed exchange rate regimes and could be mistakenly classified as flexible exchange rate regimes, this question is important to assess the different advantages of fixed exchange rate regimes versus floats.

A dummy for the occurrence of currency crisis episodes and its interaction with original sin are introduced in the regression to check whether the negative growth effect of the interaction between original sin and exchange rate volatility is limited to episodes of financial turmoil. We identify currency 
crisis through the "freely falling" episodes provided by Reinhart and Rogoff (2004). The results show that, in spite of the inclusion of a dummy for freely falling episodes and its interaction with original sin, the interaction of exchange rate flexibility and original sin is still significant. This shows that the particularly negative impact of flexible exchange rate regimes in dollarized countries highlighted before is not driven by financial turmoil episodes.

\subsubsection{Dollarized indebtment}

The original sin measure used in the baseline regressions is a composite index summarizing the inability of a country to hedge currency risk. But it does not take into account the extent to which it is exposed to this currency risk, that is debt liabilities. The amount of indebtment should qualify the importance of original sin. We therefore construct another variable incorporating both original sin and debt liabilities, and defined as: $O S I N 2=O S I N * D E B T L$, where $D E B T L$ refers to external debt liabilities over GDP (Lane and Milesi-Ferretti, 2006). Column (3) provides the regression with this alternative original sin measure. The results are reinforced: the coefficient is now significant at the $1 \%$ level.

\subsubsection{Developing versus Industrial countries}

Columns (4) to (6) try to determine whether our results are due to the fact that original sin is very high in developing countries and low in industrial economies in general. The results could reflect only the fact that exchange rate flexibility is bad for growth in emerging economies as other authors have already shown, without proving necessarily the role of dollarization. This objection is justified by the observation that original sin is very correlated with the fact of being a developing or industrial country (see Figure 3 and the correlation between initial productivity and original sin in Appendix C).

A dummy for industrial countries and its interaction with exchange rate flexibility are thus added in columns (4) and (5), with our alternative measures of original sin. Consider column (4), which uses OSIN as a measure of dollarization. The results are robust: the coefficient is stable and remains significant at the $5 \%$ level. However, original sin being very stable in the sample of developing countries, the effect of the interaction term is identified mainly through the variation between industrial countries. To overcome this problem, the second measure of original sin (OSIN2), incorporating debt liabilities and which thus provides more variability among developing countries, is used in column (5). The interaction term remains stable and significant.

Finally, column (6) excludes industrial countries from the sample. The sample size being significantly reduced, the less significant control variables (namely trade openness and government burden) are excluded. Since OSIN shows little variability in developing countries, OSIN2 is used as a measure of dollarization in this regression. Here again, the interaction term is robustly negative. 


\subsection{Endogeneity issues}

One important reproach that can be addressed to our results is the question of endogeneity. Two different strategies are adopted to deal with this problem: 1) exogeneity tests are conducted within the GMM methodology, 2) the endogeneity issue is dealt with by examining the existing empirical evidence on the determinants of original sin and exchange rate flexibility. This last discussion enables us to (i) address the the simultaneity issue by introducing additional variables that could be correlated with both growth and dollarization; and (ii) to propose an external instrumental variable for original sin.

First, note that the system-GMM methodology deals with the endogeneity of the lagged explanatory variable. Still, the procedure is valid only under our assumption that the other regressors are predetermined, which means that the regressors are uncorrelated with the current and future realizations of the error term, and uncorrelated with fixed effects. This condition can be tested by a Sargan test of overidentification which assesses the overall validity of the instruments. All the Sargan tests of the tables accept the validity of the set of instruments. Besides, as highlighted by Aghion et al. (2009), the interaction term is less vulnerable to potential endogeneity issues than the corresponding linear terms, because it identifies contrasting growth effects. Indeed, the use of interactions is similar to the difference-in-difference method. Even though the linear effect of original sin of exchange rate flexibility might be biased, the effect of exchange rate flexibility, given the level of original sin, can still be accurate.

Second, the literature has looked for the causes of original sin: Hausmann and Panizza (2003) find weak support for the idea that the level of development, institutional quality, monetary credibility or fiscal solvency is correlated with original sin. Only the absolute size of the economy is robustly correlated. Other studies analysed the determinants of other variables that could be partly related to original sin. Mehl and Reynaud (2005) show that inflation - which is already included in the present growth regressions - debt service to GDP, the slope of the yield curve and the investor base influence domestic original sin. Levy-Yeyati (2006) finds that institutional variables and inflation, but also pass-through and the procyclicality of the real exchange rate, have an impact on domestic dollarization. To study the impact of dollarization on growth, he uses restrictions on onshore foreign currency deposits (De Nicolo et al., 2003) as an instrument. The degree of pass-through and the correlation of the real exchange rate with growth are not sufficiently correlated with our index to be used as instruments in our study. However, restrictions on foreign currency deposits appears as a good instrument for external original sin, so we use them as an external instrument inside the GMM methodology. Concerning debt and institutions, since they could also have an impact on growth, I include them in the regressions to check for robustness.

As for exchange rate flexibility, some determinants have been highlighted in the literature. Hau (2002) show that trade openness is an important factor in explaining real exchange rate volatility. This variable is already included in our regressions in the robustness checks. Hausmann et al. (2006) find that growth has a significantly positive effect on real exchange rate volatility. This should bias the effect of exchange rate volatility upwards. Therefore, if the coefficient is negative despite this positive bias, our interpretations remain correct..$^{13}$

\footnotetext{
${ }^{13}$ For further discussion of the endogeneity issues associated with exchange rate flexibility, see Aghion et al. (2009).
} 
Consider Table 3. Column (1) deals with the simultaneity issue by introducing the average of Kaufmann et al. (1999) Governance indicators, which should account for institutional quality and net external debt as a share of GDP (Lane and Milesi-Ferretti, 2006). The inflation rate is also maintained, since it has also been pointed to as a cause for liability dollarization. The interaction between original sin and exchange rate flexibility is still negative and the main results are unchanged. The interaction term loses accuracy, but remains statistically significant at the $10 \%$ level. The signs of the additional variables are sensible: institutional quality favors growth while net debt is damaging.

Column (2) uses restrictions on foreign currency deposits from De Nicolo et al. (2003) and its interaction with exchange rate flexibility to instrument original sin and its interaction. The negative effect of the interaction still appears as robust. ${ }^{14}$

As a conclusion, the nonlinear effect of exchange rate flexibility and original sin on growth is globally robust to the inclusion of additional controls and to the use of an alternative measure of original sin: exchange rate flexibility has a more negative impact on productivity growth in dollarized than in nondollarized countries. Besides, this additional negative effect is not due to exchange rate crisis episodes. Additionally, the high concentration of original sin in developing country is not driving our results. Finally, the results are robust to endogeneity treatments.

\section{Conclusion}

This paper discusses the conventional view that there is no significant difference in the growth performances of fixed and flexible exchange rate regimes. This view has been misleadingly vehicled by the empirical literature because usually the specificity of emerging markets financial systems is not taken into account. Whereas Aghion et al. (2009) highlight the role of financial development, this paper focuses on original sin, which is another prominent feature of the developing world. A theoretical model is developed, in which the higher the share of foreign currency in external debt, the more exchange rate volatility is detrimental to growth, which is in line with the empirical results of section 4: the interaction of exchange rate flexibility with original sin has a negative impact. It appears also that, in absolute terms, exchange rate flexibility is growth-reducing in highly dollarized countries and growth-enhancing in low dollarization countries. Consistently, the threshold original sin above which exchange rate risk becomes detrimental to growth is estimated to be significantly between zero and one. This sheds some light on the instability of the effect of exchange rate volatility on growth in previous literature. We also show that these predictions survive robustness checks and endogeneity treatment.

The study of the impact of exchange rate flexibility on growth can help address the issue of the choice of monetary framework in a setting of financial openness and growing cross-country capital flows. The available choices are delimited by the "trilemma" (Obstfeld et al., 2005): under capital mobility, policymakers cannot attain simultaneously exchange rate stability and domestically-oriented monetary

\footnotetext{
${ }^{14}$ Interestingly, when adding additional variables and controlling for endogeneity, the linear term becomes unsignificant, which does not contradict previous evidence in the literature.
} 
policy. Typically, adopting an exchange rate peg entails the sacrifice of the shock absorption capacity of exchange rate flexibility when nominal prices and wages are sticky. This is indeed the case in this paper's theoretical framework. However, liability dollarization makes it more difficult for the emerging countries that embrace financial globalization to adopt floating exchange rates and explains why they exhibit "fear of floating" (Hausmann et al., 2001; Calvo and Reinhart, 2002). This study sheds some additional light on the reasons why developing economies find it hard to draw a comfortable resolution of the trilemma.

Acknowledgements: I am grateful to Agnès Bénassy-Quéré, Daniel Cohen, Guy Laroque, Philippe Martin, Valérie Mignon, Romain Rancière, Hélène Rey, seminar participants at CREST and EQUIPPE (Lille), the RIEF 2007 conference and 2008 doctoral meeting, the 2007 ESEM meeting, the 2008 T2M conference and the 2008 SMYE meeting for helpful comments. All remaining errors are mine. 


\section{Appendix}

\section{Appendix A: Proofs}

\section{The log-linearized, reduced-form model}

Let $x_{t}$ denote the deviation from the non-stochastic steady state of $X_{t}: x_{t}=\frac{X_{t}-X}{X} \backsim \ln \left(X_{t}\right)-\ln (X)$.

We are interested in the behavior of $\pi$ (time subscripts are dropped for simplicity). We thus loglinearize (6) and use the labor demand (5) to infer:

$$
\pi=\underbrace{(1-\kappa)(\eta+1) y^{T}+\kappa\left(p^{N}-p^{T}+y^{N}\right)}_{\text {Gross profit effect }}+\underbrace{(1-\kappa) \eta(1-\alpha) p^{T}}_{\text {Debt valuation effect }}
$$

where $\kappa=\frac{\frac{P^{N 2}}{2 P^{T} W}}{1-\left(1+r^{*}\right) d+\frac{P^{N 2}}{2 P^{T} W}}$ denotes the steady-state share of nontradables in the cash flows and $\eta=$ $\frac{\left(1+r^{*}\right) d}{1-\left(1+r^{*}\right) d}$ denotes the steady-state ratio of debt repayments over the tradable consumption (tradable profit minus debt repayments). We have $0<\kappa<1$ and $\eta>0$. The first and second terms of $\pi$ represent respectively the tradable and nontradable gross profits valued in terms of tradables (or dollars). The last term represents the effect of the debt currency composition on the financing capacities of firms. For example, everything equal, a nominal exchange rate depreciation (appreciation), that is a rise in $p^{T}$ (a fall) leads to a depreciation (appreciation) in the value of the nontradable gross profits, but it also alleviates (increases) the peso-denominated part of the debt when $\alpha<1$. If $\alpha=1$, debt repayments in terms of tradables are immune to nominal exchange rate variations and cannot hedge the variations in the tradable value of profits. However, one needs to consider how $y^{T}, y^{N}, p^{T}$ and $p^{N}$ vary jointly. To know how $\pi$ reacts to the productivity shock $u$, it is then sufficient to know the behavior of production and prices, which we can derive from the following reduced-form model.

The log-linearization of the relative demand for tradables and nontradables (10) $\left(p^{N}-p^{T}=\frac{1}{\theta}\left(c^{T}-c^{N}\right)\right)$ and the equilibrium conditions $(14)\left(c^{N}=y^{N}\right)$ and $(15)\left(c^{T}=(\eta+1) y^{T}+\eta(1-\alpha) p^{T}\right)$ gives:

$$
p^{N}-p^{T}=\frac{1}{\theta}\left[(\eta+1) y^{T}+\eta(1-\alpha) p^{T}-y^{N}\right]
$$

The relative price of nontradables in terms of tradables has to fall either if the production of nontradables rises or if the production of tradables falls. This also happens if $\alpha<1$ and the nominal exchange rate appreciates ( $p^{T}$ falls), because this makes the peso-denominated debt increase which leaves less tradable goods to consume for the household.

Besides, the log-linearization of supply of nontradables $(4)\left(y^{N}=\frac{l}{2}\right)$ and the labor demand (5) $\left(p^{N}+y^{N}=l\right)$ yields:

$$
y^{N}=p^{N}
$$

Here we see that a deflation in $p^{N}$ has a contractionary effect on $y^{N}$. This is because nominal wages are preset. As a consequence, a deflation in $p^{N}$ depresses the production of nontradables through the rise of the real wage.

Moreover, by log-linearizing the supply for tradables (3), we obtain:

$$
y^{T}=u
$$


Finally, the two possible policy choices are the following:

- Flexible exchange rate:

$$
p=0
$$

Besides, according to $(11)\left(p=\gamma p^{T}+(1-\gamma) p^{N}\right)$ the flexible rule reduces to:

$$
p^{T}=\frac{-(1-\gamma)}{\gamma} p^{N}
$$

- Fixed exchange rate:

$$
p^{T}=0
$$

With only (17), (18), (19) and one of the two monetary rules (20) or (21), $\pi$ can be inferred.

\section{Reactions of quantities and prices to shocks}

The reduced form model composed of (17), (18), (19) and one of the two monetary rules (20) or (21) is solved to obtain the following Lemma:

\section{Lemma 1}

- Under a flexible exchange rate,

$$
\begin{aligned}
& p^{N \text { flex }}=\frac{\gamma(\eta+1) u}{\theta+\gamma+(1-\gamma) \eta(1-\alpha)}, \quad p^{T \text { flex }}=\frac{(1-\gamma)(\eta+1) u}{\theta+\gamma+(1-\gamma) \eta(1-\alpha)} \\
& p^{N \text { flex }}-p^{T \text { flex }}=\frac{(\eta+1) u}{\theta+\gamma+(1-\gamma) \eta(1-\alpha)} \\
& y^{N f l e x}=\frac{\gamma(\eta+1) u}{\theta+\gamma+(1-\gamma) \eta(1-\alpha)}, \quad y^{\text {Tflex }}=u
\end{aligned}
$$

- Under a fixed exchange rate,

$$
\begin{gathered}
p^{N f i x}=\frac{(\eta+1) u}{\theta+1}, \quad p^{T f i x}=0, \quad p^{N f i x}-p^{T f i x}=\frac{(\eta+1) u}{\theta+1} \\
y^{N f i x}=\frac{(\eta+1) u}{\theta+1}, \quad y^{T f i x}=u
\end{gathered}
$$

Lemma 1 is used to establish Proposition 1:

\section{Proof of Proposition 1}

- From Lemma 1, if $u<0$ :

$y^{N f l e x}>y^{N f i x} \Leftrightarrow \gamma(\theta+1)<\theta+\gamma+(1-\gamma) \eta(1-\alpha) \Leftrightarrow(1-\gamma)[\theta+\eta(1-\alpha)]>0$ : always true.

$p^{N \text { flex }}-p^{T \text { flex }}<p^{N f i x}-p^{T f i x} \Leftrightarrow \theta+1>\theta+\gamma+(1-\gamma) \eta(1-\alpha) \Leftrightarrow \alpha>1-\frac{1}{\eta}$, true for $\alpha=1$.

- From Lemma $1, y^{N \text { flex }}$ and $p^{N \text { flex }}-p^{T \text { flex }}$ are both decreasing in $(1-\alpha)$. 


\section{Proof of Proposition 2}

- From Lemma 1, we derive:

$$
y^{N \text { flex }}+p^{N \text { flex }}-p^{\text {Tflex }}=\frac{\kappa(1+\gamma)(\eta+1) u}{\theta+\gamma+(1-\gamma) \eta(1-\alpha)}<y^{N \text { fix }}+p^{N \text { fix }}-p^{T \text { fix }}=\frac{2 \kappa(\eta+1) u}{\theta+1}
$$

if $u<0$ :

$$
\begin{gathered}
\Leftrightarrow \frac{(\kappa(1+\gamma)(\eta+1)}{\theta+\gamma+(1-\gamma) \eta(1-\alpha)}>\frac{2 \kappa(\eta+1)}{\theta+1} \\
\Leftrightarrow \kappa(1+\gamma)(\theta+1)>2 \kappa[\theta+\gamma+(1-\gamma) \eta(1-\alpha)]
\end{gathered}
$$

after rearranging:

$$
\Leftrightarrow \alpha>1-\frac{\kappa(1-\theta)}{\eta}
$$

is true for $\alpha=1$ since $\theta<1$

- $y^{N \text { flex }}+p^{N \text { flex }}-p^{\text {Tflex }}$ is decreasing in $(1-\alpha)$.

\section{Proof of Proposition 3}

From Lemma 1, we derive:

$$
\begin{aligned}
\pi^{f l e x}(u) & =\frac{[\theta+\gamma+\kappa(1-\theta)](\eta+1)}{\theta+\gamma+(1-\gamma) \eta(1-\alpha)} u \\
\pi^{f i x}(u) & =\frac{[\theta+1+\kappa(1-\theta)](\eta+1)}{\theta+1} u
\end{aligned}
$$

$\Pi^{i}=E(\Pi)+\pi^{i}, i=\{f l e x, f i x\}$, so $\Pi^{f l e x}$ and $\Pi^{f i x}$ are of the same form as (2), with the following resulting aggregate shocks:

$$
\begin{aligned}
\sigma^{\pi f l e x} & =\frac{[\theta+\gamma+\kappa(1-\theta)](\eta+1)}{\theta+\gamma+(1-\gamma) \eta(1-\alpha)} \sigma \\
\sigma^{\pi f i x} & =\frac{[\theta+1+\kappa(1-\theta)](\eta+1)}{\theta+1} \sigma
\end{aligned}
$$

- According to section 2.2.3, a fixed exchange rate yields higher growth than a flexible one (that is, $\left.E\left(\rho^{f i x}\right)>E\left(\rho^{\text {flex }}\right)\right)$, if and only if $\sigma^{\pi f l e x}>\sigma^{\pi f i x}$.

$\sigma^{\pi f l e x}>\sigma^{\pi f i x} \Leftrightarrow[\theta+\gamma+\kappa(1-\theta)](\theta+1)>[\theta+1+\kappa(1-\theta)][\theta+\gamma+(1-\gamma) \eta(1-\alpha)]$

$\Leftrightarrow \alpha>1-\frac{\kappa(1-\theta)}{\eta[1+\kappa+(1-\kappa) \theta]}:$ true for $\alpha=1$ since $\theta<1$.

- $\sigma^{\pi f l e x}-\sigma^{\pi f i x}$ is a measure of the growth differential between the fixed and flexible exchange rate regimes.

We have $\frac{\partial\left(\sigma^{\pi f l e x}-\sigma^{f f i x}\right)}{\partial \alpha}=\frac{\partial \sigma^{\pi f l e x}}{\partial \alpha}>0$, which means that the growth differential decreases when $\alpha$ diminishes.

- $\sigma^{\pi f i x}>\sigma^{\pi f l e x} \Leftrightarrow \alpha>1-\frac{\kappa(1-\theta)}{\eta[1+\kappa+(1-\kappa) \theta]}$ and $1-\frac{\kappa(1-\theta)}{\eta[1+\kappa+(1-\kappa) \theta]}>0 \Leftrightarrow \frac{\kappa(1-\theta)}{\eta[1+\kappa+(1-\kappa) \theta]}<1$

This means that if the indebtment level $\eta$ and the elasticity of substitution $\theta$ are high and if the share of nontradable production $\kappa$ is low, then there exist a level of dollarization $\alpha>0$ under which a peg is more growth-enhancing than a float. 


\section{Appendix B: Countries in sample}

\begin{tabular}{|c|c|c|}
\hline Asia & Latin America & Sub-Saharan Africa \\
\hline China & Argentina & Kenya (only 95-99) \\
\hline Hong Kong, China & Bolivia (only 95-99) & Mauritius \\
\hline India & Brazil & South Africa \\
\hline Indonesia & Chile & Zimbabwe (only 95-99) \\
\hline Korea, Rep. & Colombia & Industrial countries \\
\hline Malaysia & Costa Rica & Australia \\
\hline Pakistan & Dominican Republic & Austria (only 00-04) \\
\hline Philippines & Ecuador & Belgium (only 00-04) \\
\hline Singapore & El Salvador & Canada \\
\hline Sri Lanka & Guatemala & Denmark \\
\hline Thailand & Jamaica & Finland \\
\hline Transition countries & Mexico & France (only 00-04) \\
\hline Bulgaria & Nicaragua & Germany \\
\hline Czech Republic & Panama (only 95-99) & Greece \\
\hline Cyprus & Papua New Guinea (only 95-99) & Ireland \\
\hline Estonia & Peru & Italy \\
\hline Hungary (only 00-04) & Trinidad and Tobago 00-04 & Japan \\
\hline Kazakhstan (only 00-04) & Uruguay & Netherlands (only 00-04) \\
\hline Latvia & Venezuela, RB (only 95-99) & New Zealand \\
\hline Lithuania & Middle East and North Africa & Norway \\
\hline Moldova (only 95-99) & Algeria (only 95-99) & Portugal \\
\hline Poland & Bahrain (only 95-99) & Spain \\
\hline Romania (only 00-04) & Egypt, Arab Rep. (only 00-04) & Sweden \\
\hline Slovak Republic & Israel & Switzerland \\
\hline Slovenia & Oman (only 95-99) & United Kingdom \\
\hline Turkey & Tunisia & United States \\
\hline
\end{tabular}

Ukraine 95-99 


\section{Appendix C: Descriptive statistics}

Summary statistics 1995-2004 (data in five-year averages)

\begin{tabular}{llllll}
\hline Variable & Observations & Mean & Std. Dev. & Min & Max \\
\hline Productivity growth & 134 & 0,02 & 0,02 & $-0,05$ & 0,10 \\
Initial productivity & 134 & 26413,24 & 18668,75 & 2172,53 & 70091,68 \\
Financial development & 134 & 0,53 & 0,39 & 0,03 & 1,63 \\
Education & 134 & 83,79 & 28,43 & 14,00 & 158,76 \\
Trade openness & 134 & 81,38 & 46,03 & 18,11 & 322,35 \\
Inflation & 134 & 0,08 & 0,11 & $-0,02$ & 0,78 \\
Government burden & 134 & 15,87 & 5,17 & 5,52 & 29,21 \\
Kaufman governance index & 134 & 3,19 & 4,83 & $-7,06$ & 11,69 \\
Net external debt & 134 & 0,24 & 0,42 & $-2,15$ & 1,88 \\
\hline REER vol. & 90 & 0,06 & 0,04 & 0,01 & 0,19 \\
LS Index of ER flex. & 129 & 2,40 & 1,18 & 1,00 & 4,00 \\
Original sin & 134 & 0,86 & 0,22 & 0,20 & 1,00 \\
\hline
\end{tabular}




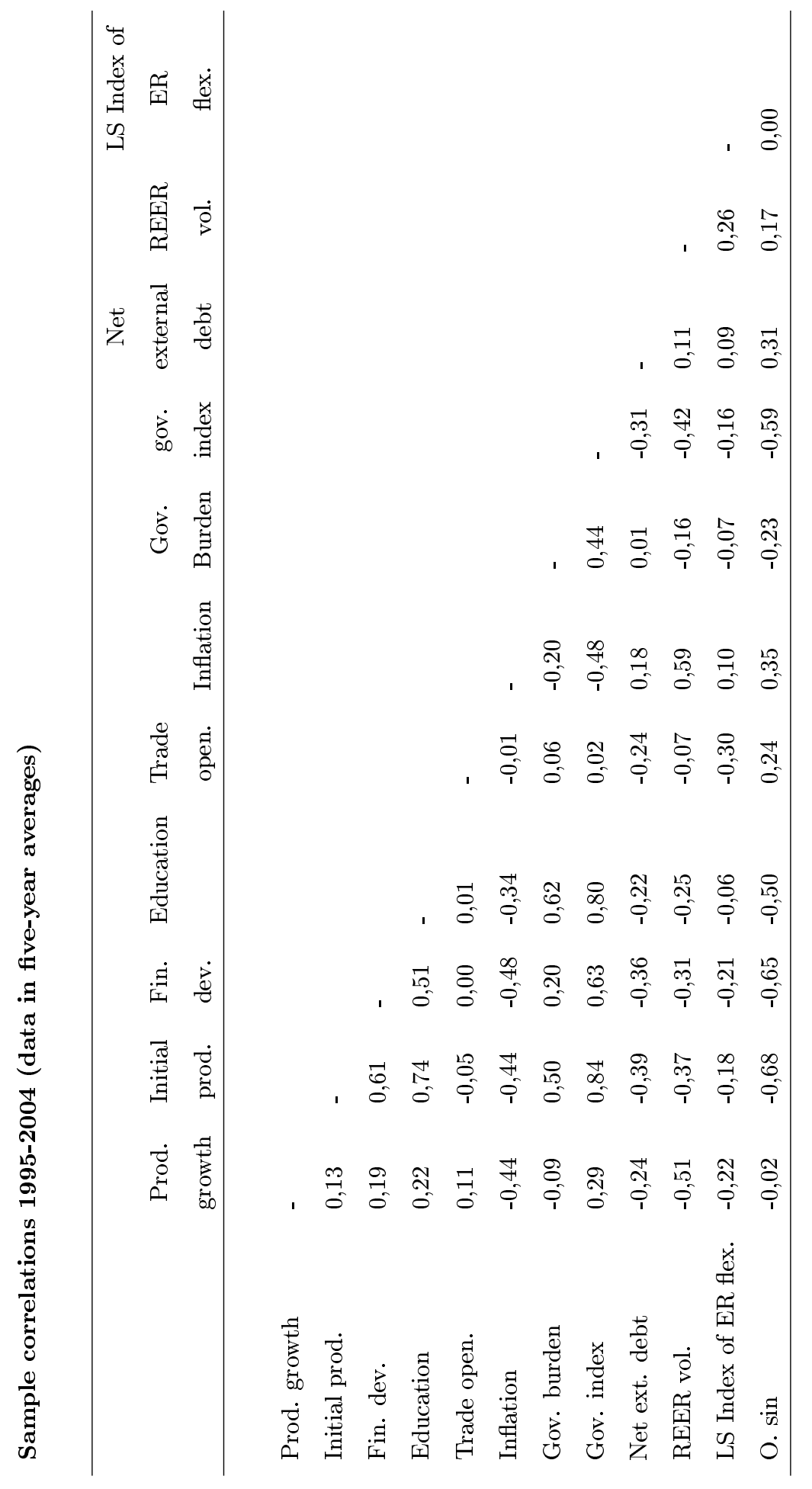




\section{References}

Aghion, P., P. Bacchetta and A. Banerjee (2000), 'A simple model of monetary policy and currency crises', European Economic Review 44(4-6), 728-738.

Aghion, Philippe, George-Marios Angeletos, Abhijit Banerjee and Kalina Manova (2005), 'Volatility and growth: Credit constraints and productivity-enhancing investment'.

Aghion, Philippe, Philippe Askenazy, Nicolas Berman, Gilbert Cette and Laurent Eymard (2007), 'Credit constraints and the cyclicality of r\&d investment: Evidence from france', Working Paper 2007-4, Weatherhead Center for International Affairs, Harvard University.

Aghion, Philippe, Philippe Bacchetta, Romain Rancière and Kenneth Rogoff (2009), 'Exchange rate volatility and productivity growth: The role of financial development'.

Arellano, M. and O. Bover (1995), 'Another look at the instrumental-variable estimation of error components models', Journal of Econometrics 68, 29-51.

Arellano, M. and S. Bond (1991), 'Some tests of specification for panel data: Monte carlo evidence and an application to employment equations', Quarterly Journal of Economics 120(1), 173-222.

Arteta, C. (2005), 'Exchange rate regimes and financial dollarization: Does flexibility reduce currency mismatches in bank intermediation?', Topics in Macroeconomics 5(1), 1226-1226. Available at: http://www.bepress.com/bejm/topics/vol5/iss1/art10.

Barro, R. J. and X. Sala-i Martin (1995), Economic Growth, McGraw Hill, New York.

Barro, Robert J. and Jong-Wha Lee (2000), 'International data on educational attainment: Updates and implications'.

Baxter, Marianne and Alan Stockman (1989), 'Business cycles and the exchange rate regime', Journal of Monetary Economics 23(3).

Beck, T., A. Demirguc-Kunt and R. Levine (1999), 'A new database on financial developement and structure', World Bank Policy Research Working Paper No 2146.

Bleaney, M. and L.C. Vargas (2009), 'Real exchange rates, valuation effects and growth in emerging markets', Open Economies Review 20, 631-43.

Blundell, R. and S. Bond (1998), 'Initial conditions and moment conditions in dynamic panel data models', Journal of Econometrics 87, 115-143.

Blundell, R. and S. Bond (2000), 'Gmm estimation with persistent panel data: An application to production functions', Econometric Reviews 19, 321-340.

Burnside, C., M. Eichenbaum and S. Rebelo (2001), 'Hedging and financial fragility in fixed exchange rate regimes', European Economic Review 45(7), 1151-93. 
Calvo, G. A. and C. M. Reinhart (2002), 'Fear of floating', Quarterly Journal of Economics 117, 379-408.

Calvo, G. and P. Guidotti (1989), 'Credibility and nominal debt: Exploring the role of maturity in managing inflation', IMF Working Paper No 89/73.

Calvo, Guillermo (2000), 'Capital markets and the exchange rate with special reference to the dollarization debate in latin america', http://www.bsos.umd.edu/econ/ciecrp9.pdf.

Calvo, Guillermo, Alejandro Izquierdo and Luis-Fernando Mejia (2004), 'On the empirics of sudden stops: The relevance of balance-sheet effects'.

Cespedes, Luis Felipe, Roberto Chang and Andres Velasco (2002), 'Balance sheets and exchange rate policy', American Economic Review 94(4), 1183-93.

Christiano, L., C. Gust and J. Roldos (2004), 'Monetary policy in a financial crisis', Journal of Economic Theory 119, 64-103.

Cook, David (2004), 'Monetary policy in emerging markets: Can liability dollarization explain contractionary devaluations?', Journal of Monetary Economics 51, 1155-1181.

Cook, W. G. and D. Cook (2002), 'Liability dollarization and the bank balance sheet channel', IMF Working Paper No WP/02/141.

De la Torre, A., E. Levy Yeyati and S. L. Schmukler (2003), 'Living and dying with hard pegs: The rise and fall of argentina's currency board', Economia 3(2), 43-99.

De Nicolo, G., P. Honohan and A. Ize (2003), 'Dollarization of the banking system : good or bad?', Policy Research Working Paper Series 3116, The World Bank.

Devereux, M. B., P. R. Lane and J. Xu (2006), 'Exchange rates and monetary policy in emerging market economies', Economic Journal 116(511), 478-506.

Dubas, J.M., B.-J. Lee and N.C. Mark (2005), 'Effective exchange rate classifications and growth', NBER Working Paper No 11272.

Eichengreen, B., R. Hausmann and U. Panizza (2005), 'The pain of original sin', in Other People ̌̌s Money: Debt Denomination and Financial Instability in Emerging-Market Economies, B. Eichengreen and R. Hausmann (ed.), University of Chicago Press.

Eichengreen, Barry and Ricardo Hausmann (1999), 'Exchange rates and financial fragility', NBER Working Paper No 7418.

Galiani, S., Levy-Yeyati E. and E. Schargrodsky (2003), 'Financial dollarization and debt deflation under a currency board', Emerging Markets Review 4, 340-367.

Hau, H. (2002), 'Real exchange rate volatility and economic openness: Theory and evidence', Journal of Money, Credit and Banking 34(3), 611-630. 
Hausmann, R., U. Panizza and R. Rigobon (2006), 'The long-run volatility puzzle of the exchange rate', Journal of International Money and Finance 25, 93-124.

Hausmann, Ricardo and Hugo Panizza (2003), 'On the determinants of original sin: an empirical investigation', Journal of International Money and Finance 22(7).

Hausmann, Ricardo, Hugo Panizza and Ernesto Stein (2001), 'Why do countries float the way they float?', Journal of Development Economics 2(66).

Husain, A. M., A. Mody and K. Rogoff (2005), 'Exchange rate regime durability and performance in developing versus advanced economies', Journal of Monetary Economics 52(1).

Kamil, H. (2008), 'How do exchange rate regimes affect firms' incentives to hedge exchange rate risk', mimeo.

Kaufmann, D., A. Kraay and P. Zoido-Lobaton (1999), 'Aggregating governance indicators', World Bank Policy Research Working Paper No 2195.

Krugman, Paul (2000), 'Analytical afterthoughts on the asian crisis', in http://web.mit.edu/krugman/www/MINICRIS.htm.

Lane, Philip R. and Gian Maria Milesi-Ferretti (2006), 'The external wealth of nations mark ii: Revised and extended estimates of foreign assets and liabilities for industrial and developing countries, 19702004', IMF Working Paper (69).

Levine, R., Norman Loayza and T. Beck (2000), 'Financial intermediation and growth: Causality and causes', Journal of Monetary Economics 46(1), 31-77.

Levy-Yeyati, E. and F. Sturzenegger (2002), 'Classifying exchange rate regimes: Deeds vs. words', Mimeo, Universidad Torcuato Di Tella available at www.utdt.edu/ fsturzen.

Levy-Yeyati, E. and F. Sturzenegger (2003), 'To float or to fix: Evidence on the impact of exchange rate regimes on growth', American Economic Review 93(4), 1173-1193.

Levy-Yeyati, Eduardo (2006), 'Financial dollarization: Evaluating the consequences', Economic Policy (january), 61-118.

Lorenzo, Fernando, Diego Aboal and Rosa Osimani (2005), 'The elasticity of substitution in demand for non-tradable goods in uruguay', Inter-American Development Bank Research Network Working paper No R-480.

Mehl, Arnaud and Julien Reynaud (2005), "The determinants of "domestic" original sin in emerging market economies', ECB Working Paper No 560.

Mendoza, E. (1997), 'Terms-of-trade uncertainty and economic growth', Journal of Development Economics 54(2), 323-356. 
Mendoza, Enrique G. (2001), 'Credit, prices and crashes: Business cycles with a sudden stop', NBER Working Paper No 8338.

Obstfeld, M., J C. Shambaugh and A. M. Taylor (2005), 'The trilemma in history: Tradeoffs among exchange rates, monetary policies, and capital mobility', Review of Economics and Statistics 87(3), 42338.

Razin, Assaf and Yona Rubinstein (2006), 'Evaluation of currency regimes: the unique role of sudden stops', Economic Policy 46, 119-152.

Reinhart, Carmen M. and Kenneth S. Rogoff (2004), 'The modern history of exchange rate arrangements: A reinterpretation', Quarterly Journal of Economics 119(1), 1-48.

Reinhart, Carmen M., Kenneth S. Rogoff and M. Savastano (2003), 'Addicted to dollars', NBER Working Paper No 10015.

Windmeijer, F. (2004), 'A finite sample correction for the variance of linear two-step gmm estimator', Journal of Econometrics 126(1), 25-51. 
Table 1: Growth effect of the flexibility of Exchange Rate Regime and its channels - 2-step system-GMM estimation with Windmeijer (2004) small sample robust correction and time effects

\begin{tabular}{|c|c|c|c|c|c|}
\hline & $(1)$ & $(2)$ & $(3)$ & $(4)$ & $(5)$ \\
\hline \multirow[t]{2}{*}{ Initial output per worker } & -0.006 & 0.005 & -0.002 & 0.000435 & 0.00327 \\
\hline & $(0.008)$ & $(0.006)$ & $(0.006)$ & $(0.00733)$ & $(0.00556)$ \\
\hline \multirow[t]{2}{*}{ Financial development } & 0.008 & 0.004 & 0.004 & 0.00466 & 0.00246 \\
\hline & $(0.005)$ & $(0.005)$ & $(0.004)$ & $(0.00740)$ & $(0.00888)$ \\
\hline \multirow[t]{2}{*}{ Original sin } & & $0.058^{* * *}$ & $0.056^{* * *}$ & $0.0364^{*}$ & $0.0511^{* * *}$ \\
\hline & & $(0.021)$ & $(0.016)$ & $(0.0207)$ & $(0.0181)$ \\
\hline \multirow[t]{2}{*}{ LS Flexibility Index } & $-0.006 * * *$ & $0.009^{* *}$ & $0.005^{*}$ & & $0.00793^{* *}$ \\
\hline & $(0.002)$ & $(0.004)$ & $(0.003)$ & & $(0.00368)$ \\
\hline \multirow[t]{2}{*}{ LS Flexibility*Original sin } & & $-0.016^{* *}$ & -0.008 & & $-0.0139 * *$ \\
\hline & & $(0.006)$ & $(0.005)$ & & $(0.00674)$ \\
\hline \multirow[t]{2}{*}{ Real effective exchange rate volatility } & & & 0.234 & $0.400^{*}$ & \\
\hline & & & $(0.181)$ & $(0.215)$ & \\
\hline \multirow[t]{2}{*}{ REER volatility*Original sin } & & & $-0.516^{* *}$ & $-0.617^{* *}$ & \\
\hline & & & $(0.206)$ & $(0.259)$ & \\
\hline \multirow[t]{2}{*}{ Terms of trade volatility } & & & & -0.516 & \\
\hline & & & & $(0.553)$ & \\
\hline \multirow[t]{2}{*}{ TT volatility* Original sin } & & & & 0.465 & \\
\hline & & & & $(0.569)$ & \\
\hline \multirow[t]{2}{*}{ LS Flexibility*Financial development } & & & & & 0.000704 \\
\hline & & & & & $(0.00272)$ \\
\hline \multirow[t]{2}{*}{ Effect of LS flex. when O.sin $=1$} & & $-0.007^{* *}$ & -0.004 & & -0.006012 \\
\hline & & $(0.003)$ & 0.003 & & 0.0038568 \\
\hline Wald test (F-statistic): & & $3.42^{* *}$ & 1.49 & & $2.37^{*}$ \\
\hline \multicolumn{6}{|l|}{$H_{0}:$ LS flex. total effect $=0$} \\
\hline Threshold Original sin & & 0.56 & 0.63 & & 0.57 \\
\hline$H_{0}:$ Threshold $=0$ (F-statistic) & & $40.86^{* * *}$ & $16.20^{* * *}$ & & $19.89^{* * *}$ \\
\hline$H_{0}:$ Threshold $=1$ (F-statistic) & & $23.39^{* * *}$ & $9.01 * * *$ & & $11.43^{* * *}$ \\
\hline \multicolumn{6}{|l|}{ Hansen overidentification test } \\
\hline$H_{0}$ Valid instruments $($ Prob $>$ chi2) & 0.064 & 0.123 & 0.524 & 0.892 & 0.199 \\
\hline Observations & 132 & 132 & 88 & 72 & 132 \\
\hline Number of countries & 76 & 76 & 51 & 40 & 76 \\
\hline
\end{tabular}

Robust t statistics in parentheses

* significant at $10 \% ; * *$ significant at $5 \% ; * * *$ significant at $1 \%$ 
Table 2: Growth effects of the flexibility of Exchange Rate Regime - Robustness checks - 2-step systemGMM estimation with Windmeijer (2004) small sample robust correction and time effects

\begin{tabular}{|c|c|c|c|c|c|c|}
\hline & $(1)$ & $(2)$ & $(3)$ & $(4)$ & $(5)$ & $\begin{array}{l}(6) \\
\text { Excluding } \\
\text { industrial }\end{array}$ \\
\hline Initial output per worker & $\begin{array}{l}-0.015^{* *} \\
(0.007)\end{array}$ & $\begin{array}{l}-0.00713 \\
(0.00699)\end{array}$ & $\begin{array}{l}-0.012^{*} \\
(0.007)\end{array}$ & $\begin{array}{l}-0.0130 \\
(0.00894)\end{array}$ & $\begin{array}{l}-0.013^{*} \\
(0.008)\end{array}$ & $\begin{array}{l}-0.015^{*} \\
(0.008)\end{array}$ \\
\hline Financial development & $\begin{array}{l}-0.001 \\
(0.008)\end{array}$ & $\begin{array}{l}-0.00318 \\
(0.00504)\end{array}$ & $\begin{array}{l}-0.002 \\
(0.004)\end{array}$ & $\begin{array}{l}-0.00183 \\
(0.00855)\end{array}$ & $\begin{array}{l}-0.001 \\
(0.004)\end{array}$ & $\begin{array}{l}0.004 \\
(0.004)\end{array}$ \\
\hline Original sin & $\begin{array}{l}0.028 \\
(0.022)\end{array}$ & $\begin{array}{l}0.0383^{* *} \\
(0.0158)\end{array}$ & & $\begin{array}{l}0.0353 \\
(0.0256)\end{array}$ & & \\
\hline Original Sin 2 & & & $\begin{array}{l}0.010 * \\
(0.006)\end{array}$ & & $\begin{array}{l}0.009 \\
(0.006)\end{array}$ & $\begin{array}{l}0.015^{* *} \\
(0.007)\end{array}$ \\
\hline LS Flexibility Index & $\begin{array}{l}0.005^{*} \\
(0.003)\end{array}$ & $\begin{array}{l}0.00676 * * \\
(0.00285)\end{array}$ & $\begin{array}{l}0.002 \\
(0.002)\end{array}$ & $\begin{array}{l}0.00815 \\
(0.00665)\end{array}$ & $\begin{array}{l}-0.000 \\
(0.003)\end{array}$ & $\begin{array}{l}-0.000 \\
(0.004)\end{array}$ \\
\hline LS Flexibility*Original sin & $\begin{array}{l}-0.011^{* *} \\
(0.005)\end{array}$ & $\begin{array}{l}-0.0132 * * * \\
(0.00429)\end{array}$ & & $\begin{array}{c}-0.0141^{* *} \\
(0.00693)\end{array}$ & & \\
\hline LS Flexibility*Original $\sin 2$ & & & $\begin{array}{l}-0.014^{* * *} \\
(0.005) \\
\end{array}$ & & $\begin{array}{l}-0.013^{* *} \\
(0.006)\end{array}$ & $\begin{array}{l}-0.019^{* * *} \\
(0.007)\end{array}$ \\
\hline \multicolumn{7}{|l|}{ Control variables } \\
\hline Education & $\begin{array}{l}0.034^{* * *} \\
(0.010)\end{array}$ & $\begin{array}{l}0.0261 * * \\
(0.00988)\end{array}$ & $\begin{array}{l}0.038^{* * *} \\
(0.008)\end{array}$ & $\begin{array}{l}0.0344^{* * *} \\
(0.0109)\end{array}$ & $\begin{array}{l}0.038 * * * \\
(0.007)\end{array}$ & $\begin{array}{l}0.037 * * * \\
(0.010)\end{array}$ \\
\hline Trade openness & $\begin{array}{l}0.005 \\
(0.007)\end{array}$ & $\begin{array}{l}0.00748 \\
(0.00542)\end{array}$ & $\begin{array}{l}0.010^{* *} \\
(0.004)\end{array}$ & $\begin{array}{l}0.00536 \\
(0.00780)\end{array}$ & $\begin{array}{l}0.008 \\
(0.005)\end{array}$ & \\
\hline Inflation & $\begin{array}{l}-0.066^{* * *} \\
(0.022)\end{array}$ & $\begin{array}{l}-0.0625^{* *} \\
(0.0293)\end{array}$ & $\begin{array}{l}-0.062^{* *} \\
(0.027)\end{array}$ & $\begin{array}{l}-0.0678^{* * *} \\
(0.0202)\end{array}$ & $\begin{array}{l}-0.063^{* *} \\
(0.029)\end{array}$ & $\begin{array}{l}-0.047^{* *} \\
(0.022)\end{array}$ \\
\hline Government burden & $\begin{array}{l}-0.006 \\
(0.007)\end{array}$ & $\begin{array}{l}-0.00413 \\
(0.00743)\end{array}$ & $\begin{array}{l}-0.010^{*} \\
(0.005)\end{array}$ & $\begin{array}{l}-0.00628 \\
(0.00737)\end{array}$ & $\begin{array}{l}-0.008 \\
(0.005)\end{array}$ & \\
\hline Freely falling & & $\begin{array}{l}-0.255 \\
(0.189)\end{array}$ & & & & \\
\hline Freely falling* Original sin & & $\begin{array}{l}0.252 \\
(0.191)\end{array}$ & & & & \\
\hline Industrial country & & & & $\begin{array}{l}0.00201 \\
(0.0176)\end{array}$ & $\begin{array}{l}-0.009 \\
(0.009)\end{array}$ & \\
\hline Industrial country*LS Flexibility & & & & $\begin{array}{l}-0.00155 \\
(0.00415)\end{array}$ & $\begin{array}{l}0.003 \\
(0.003)\end{array}$ & \\
\hline Institutional quality & & & & & & \\
\hline Net external debt & & & & & & \\
\hline Hansen overidentification test & & & & & & \\
\hline$H_{0}$ Valid instruments $($ Prob $>$ chi2) & 0.597 & 0.992 & 0.606 & 0.552 & 0.566 & 0.525 \\
\hline Observations & 129 & 125 & 129 & 129 & 129 & 92 \\
\hline Number of countries & 75 & 71 & 75 & 75 & 75 & 54 \\
\hline
\end{tabular}


Table 3: Growth effects of the flexibility of Exchange Rate Regime - Endogeneity treatment - 2-step system-GMM estimation with Windmeijer (2004) small sample robust correction and time effects

\begin{tabular}{|c|c|c|}
\hline & $(1)$ & $(2)^{a}$ \\
\hline \multirow[t]{2}{*}{ Initial output per worker } & $-0.0221 * * *$ & -0.00619 \\
\hline & $(0.00734)$ & $(0.00797)$ \\
\hline \multirow[t]{2}{*}{ Financial development } & -0.00295 & -0.000736 \\
\hline & $(0.00586)$ & $(0.00655)$ \\
\hline \multirow[t]{2}{*}{ Original sin } & 0.00434 & 0.0106 \\
\hline & $(0.00364)$ & $(0.00758)$ \\
\hline \multirow[t]{2}{*}{ LS Flexibility Index } & $0.0413^{* *}$ & $0.0661^{* *}$ \\
\hline & $(0.0203)$ & $(0.0285)$ \\
\hline \multirow[t]{2}{*}{ LS Flexibility*Original sin } & $-0.0100^{*}$ & $-0.0181 * *$ \\
\hline & $(0.00531)$ & $(0.00827)$ \\
\hline \multicolumn{3}{|l|}{ Control variables } \\
\hline \multirow[t]{2}{*}{ Education } & $0.0272^{* * *}$ & $0.0281^{*}$ \\
\hline & $(0.00865)$ & $(0.0154)$ \\
\hline \multirow[t]{2}{*}{ Trade openness } & -0.000225 & 0.00667 \\
\hline & $(0.00519)$ & $(0.00631)$ \\
\hline \multirow[t]{2}{*}{ Inflation } & $-0.0536 * *$ & $-0.0571 * * *$ \\
\hline & $(0.0265)$ & $(0.0193)$ \\
\hline \multirow[t]{2}{*}{ Government burden } & -0.00626 & -0.000733 \\
\hline & $(0.00706)$ & $(0.00809)$ \\
\hline \multirow[t]{2}{*}{ Institutional quality } & $0.00262^{* *}$ & \\
\hline & $(0.00126)$ & \\
\hline \multirow[t]{2}{*}{ Net external debt } & $-0.01000^{* *}$ & \\
\hline & $(0.00495)$ & \\
\hline
\end{tabular}

\begin{tabular}{lll}
\hline Hansen overidentification test & & \\
$H_{0}$ Valid instruments (Prob $>$ chi2) & 0.849 & 0.998 \\
\hline Observations & 129 & 91 \\
Number of countries & 75 & 51 \\
\hline
\end{tabular}

Robust $\mathrm{t}$ statistics in parentheses

* significant at $10 \%$;* significant at $5 \%$;** significant at $1 \%$

a: Restrictions on onshore foreign currency deposits (De Nicolo et al., 2003) used as external instrument. 
Figure 1: The effect of a negative shock in the tradable sector $(u=-1)$
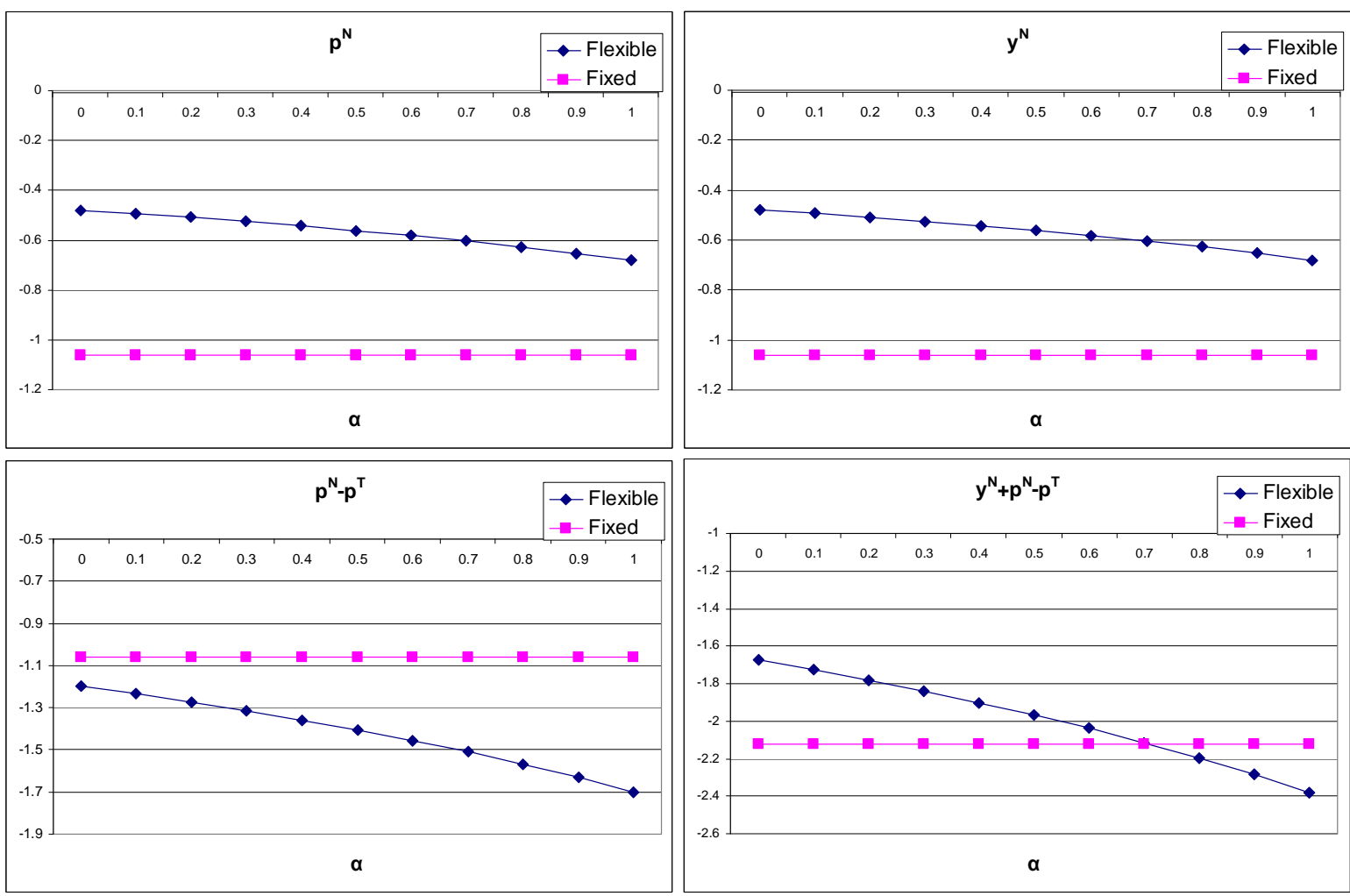

Assumptions: $\theta=0.6, \gamma=0.4, \kappa=0.6, \eta=0.7 . \eta$ denotes the steady-state ratio of debt repayments over the tradable consumption (tradable profit minus debt repayments) and $\kappa$ is the steady-state share of nontradables in cash flows. 
Figure 2: The variance of firms' cash flows

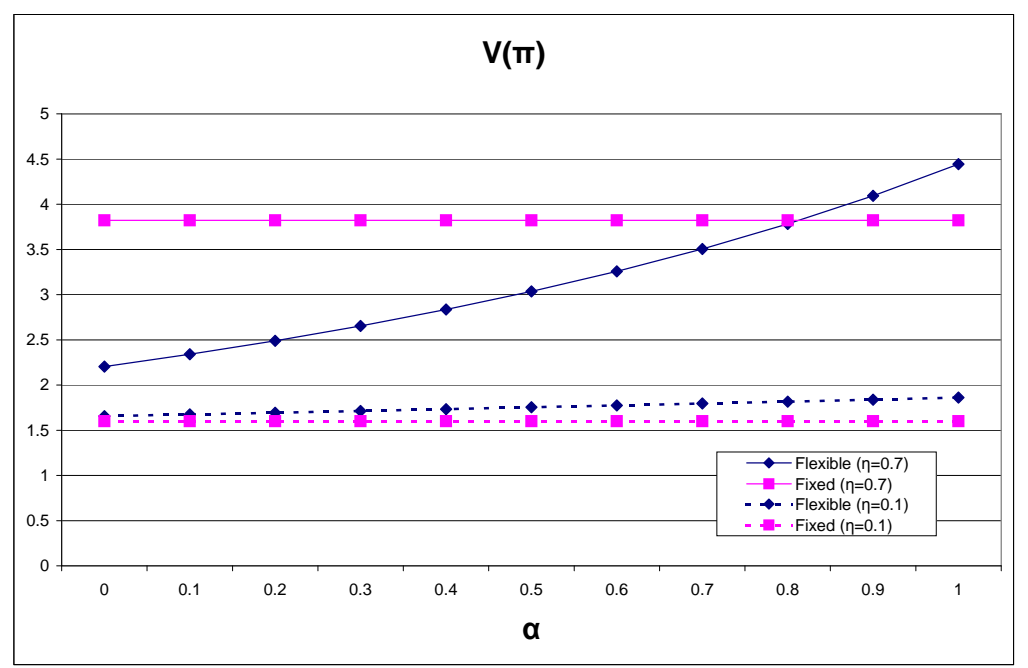

Assumptions: $\theta=0.6, \gamma=0.4, \kappa=0.6 . \eta$ denotes the steady-state ratio of debt repayments over the tradable consumption (tradable profit minus debt repayments) and $\kappa$ is the steady-state share of nontradables in cash flows. 
Figure 3: Distribution of original sin in industrial and developing countries

Industrial countries

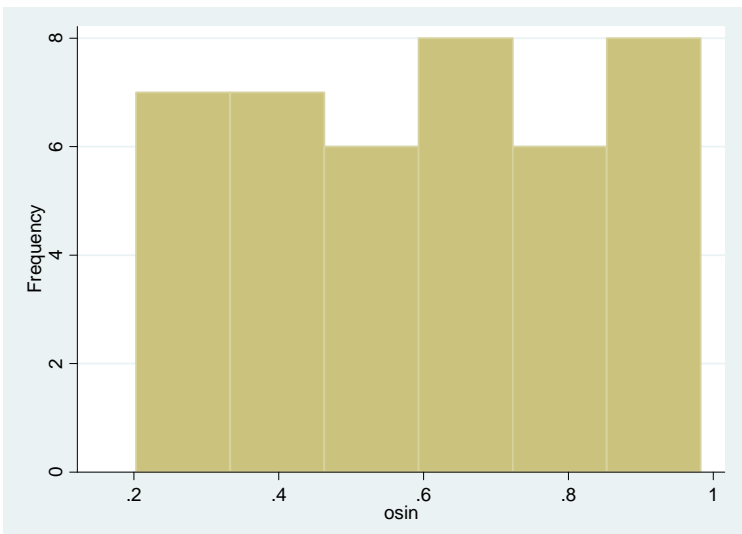

Developing countries

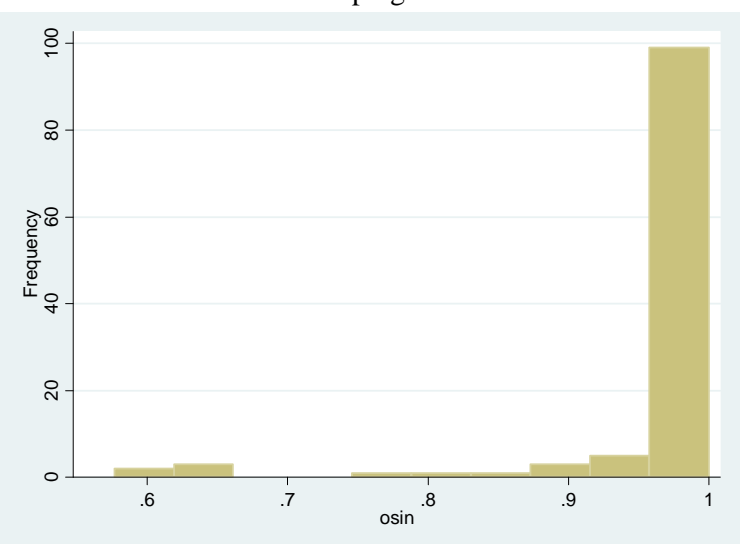

Source: Hausmann et al. (2001). 